\title{
Emakumeak eta bortxa euskal baladetan: emakumezkoen literatura-tradizio bat
}

\author{
Women and Violence in Basque Ballads: \\ a Women's Literature Tradition
}

\author{
Cristina GonZález ArtetXe \\ Universidad Nacional de Educación a Distancia \\ crisbakio@gmail.com \\ Recibido: marzo de 2020. Aceptado: abril de 2020
}

Laburpena: Artikulu honen helburua euskal ahozko literaturan bortxarekin erlazionatzen den eta gordean egon den emakume tradizio bat dagoen ebaztea da. Horretarako, bost balada aztertu dira: Andre Emili, Frantziako Anderea, Urrutiako Anderea, Neska ontziratua eta Atharratze Jauregian. Balada hauek bai formalki bai kontzeptualki aztertu dira; horretarako, baladen subjektua eta aktanteak aztertu dira, baita egitura ere; era berean, bortxa, familiaren rola eta maitasunaren irudiari erreparatzen zaio. Formen eta ideien arteko elkarreragina eta antolaketa ikertu dira, luzez ezagun suertatu zaigun eta oraindik ulertzen den errealitate baten arteko loturak nola egokitzen diren ulertzen saiatuz.

Gako-hitzak: Ahozko literatura, euskal baladak, bortxa, emakumeak, maitasuna, familia, Erdi Aroa, tradizioa, emakumezkoen literatura-tradizio bat.

Abstract: The aim of this article is to elucidate whether it exists and has been concealed a female tradition that relates to violence in Basque oral literature. Five ballads are analyzed: Andre Emili, Frantziako Anderea, Urrutiako Anderea, Neska ontziratua and Atharratze Jauregian. These ballads will be examinated both formally and conceptually, evaluating the subject and actants of the ballads, their structure, violence, the role of the family and the image of love. The interaction and organization between forms and ideas have been investigated, trying to understand how the connections between a reality that has been known by us for a long time and the one that is still understood are adapted.

Keywords: oral literature, Basque ballads, violence, women, love, family, Middle Ages, tradition, a female literary tradition. 


\section{I.-SARRERA}

Ahozko literatura zer den definitzea ez da erreza, eta asko izan dira lan horretan aritu direnak. Mircéa Éliaderen hitzetan (1955: 3), "tout ce qui a été dit, et ensuite retenu par la mémoire collective, appartient à la littérature orale. Car tous ces textes racontent, à leur manière, une histoire». Jan Vansinak (1966: 33) honela dio, berriz: «las tradiciones orales son todos los testimonios orales, narrados, concernientes al pasado. Esta definición implica que sólo las tradiciones orales, es decir, los testimonios hablados y cantados, pueden ser tenidos en cuenta». Literatura, beraz, baina ahozkoa. Paul Zumthorrek (2006: 10) «giza ahotsaren fenomenoa testu poetikoaren dimentsio gisa» aipatzen du. Zumthorrentzat, ahozkotasunak berebiziko garrantzia dauka Erdi Aroko poesiaren sortze eta transmisioan; testuak zentzumen-pertzepzio objektu gisa erreibindikatzen ditu (2006: 11), ahozkotasuna testuen helburuetariko bat delarik (2006: 39).

¿Cuál fue, en cada clase de texto -por no decir en cada texto y cada vez que fue comunicado-, el papel de la voz? [...] Cualesquiera que fueren las circunstancias y los procesos que la precediesen, acompañaran o sucediesen, con la palabra performance pretendo designar la acción vocal por la cual el texto poético era transmitido a sus destinatarios. La transmisión de boca en boca opera literalmente el texto: lo efectúa. La performance transforma una comunicación oral en un objeto poético, confiriéndole la identidad social en virtud de la cual es percibido y reconocido como tal. (2006: 40)

Euskal gizartean oso errotuta dago ahozko literatura. Bernart Etxeparek 1545 urtean euskaraz idatzitako lehen liburua Linguae Vasconum Primitiae (Urquizu 2000: 131) argitaratu zuenetik eta 1879ra, 101 liburu baino ez ziren euskaraz argitaratu (Paya 2013: 17). Idatziarekin alderatuz, euskal ahozko literatura oparoa izan da. Jabier Kaltzakortaren hitzetan (2009: 18):

Euskararen eremua bezalako biztanle kopuru mugatua eta lurralde txikian bizi den herri batena izateko, ezagutzen dugun herri-literatura corpusa ikertu eta baloratuz gero, albo herrietakoari zor handirik ez diela epai daiteke.

Honek eman dezake euskal kulturaren biziraupenean ahozko komunikazioak eta literaturak izan duten pisuaren irudia.

Ahozko literatura sailkatzeko, hainbat irizpide erabili izan da. Irizpideak era askotakoak dira, eta egileen arabera aldatzen dira. Etxebarriak eta Kaltzakortak erabilitakoari erreparatuko diot. Hau da, euskal ahozko literaturaren eremuan, beraien sailkapena: kopla zaharrak, baladak, kantu lirikoak, ipuinak, errefrauak, inauterietako antzezpenak eta gabonetakoak (2009: 18).

Artikulu honetan, hainbat balada aztertzen dira. Euskal baladak poema narratiboak dira. Normalean, istorio labur baten berri ematen dute, gertaera harrigarriak kontatzen dituzte, askotan ez dago sarrerarik eta hasieratik tentsio dramatikoa handia da eta erabaki-unean kokatzen da akzioa. Bortxaz beteriko istorioak izaten dira, askotan ezinezko maitasunak, indarkeriazko heriotzak, 
hilketak eta borroken berri ematen dutelarik (Paya 2013: 98). Pertsonaiari buruzko informazio gutxi ematen da baladetan, eta bere hitz edo ekintzen bidez aurkezten dira; era berean, apenas aurkitzen da espazio eta denborari buruzko datu zehatzik. Tentsio handiko uneak estilo zuzenaren bidez adierazten dira, elkarrizketa zorrotzen bidez. Gehienetan, eszenak inolako sarrerarik gabe aldatzen dira. Elkarrizketak, berriz, tentsio handiko uneak luzatzeko erabili ohi dira (Etxebarria, Kaltzakorta 2009: 40). Honekin guztiarekin, dramatismoa areagotzea lortzen da, ez hitzez bakarrik; eta bai jendaurrean kantatuz performance horren bidez ere.

Ahoz aho zebiltzan kanta horiek gehienetan ez zaizkigu osorik heldu. Lehenengo bilketa lana Esteban de Garibayk egin zuen; geroztik, asko izan dira lan honetan murgildu direnak. XIX. mende hasieran, Erromantizismoaren eraginez, Europan herri-ipuin, herri-elezahar eta herri-kantuak biltzen hasten zenean, Humboldtek hainbat tradiziozko kantu bildu zituen Euskal Herrian. Bestalde, XIX. mendekoak dira lehen bilduma ezagunak, Augustin Xahoren eskutik jasoak. Xx. mendean, Jean Barbier, Mayi Ariztia, Piarres Lafitte edo Resurrección $\mathrm{M}^{\mathrm{a}}$ de Azkue aipa genitzake, azken hau biltzaile emankorrenetariko bat delarik. Berarekin batera, Manuel Lekuona, Jesús M. Leizaola, «María Goyri» mintegia, Antonio Zavala, Jon Juaristi edo Labayru Ikastegiaren lanak ere aipatu behar dira (Etxebarria, Kaltzakorta 2009: 19-25). Kasu askotan, emakumezko informatzaileak izan dituzte ikertzaile hauek ${ }^{1}$ (Irastortza 2020: 36)

\section{II.- LAN HIPOTESIAK. IKERTUKO DIREN BALADAK INTERPRETATZEKO GAKOAK}

Arestian aipatutako bilduma edo antologia horietan jasotako balada guztien artean, hauek dira lan honetan aztertuko direnak: Andre Emili, Frantziako anderea, Urrutiako anderea, Neska ontziratua eta Atharratzeko jauregian.

Testu hauek hautatzeko, bi motatako irizpideak hartu dira aintzat: batetik, aniztasun kronologiko eta geografikoa. Baladen artean aniztasun kronologiko eta geografiko handia dago. Beraien jatorria eta kronologia zehaztea zaila bada ere, irizpide ezberdinak erabili dituzte ikertzaileek, hala nola erromantze argitalpenak, atsotitz bihurtutako bertso fosilduak, egile ikasiek egindako imitazio eta glosak edo bertsoetan ikusgai diren gertaera historikoak eta erabilitako hizkuntza bera (Lakarra, Biguri, Urgell 1983: 171). Etxebarriak eta Kaltzakortak baieztatzen dutenez (2009: 19), euskal ahozko literaturan lekukotasun idatzirik zaharrenak XVI. eta XVII. mendeetakoak direnez, eta ordurako tradizio bihurtuta zeudenez, bi mende lehenagokoak ere izan daitezke.

1 Tere Irastortza Garmendiak Euskarazko literatura eta letren sorkuntzako emakumeen eta gizonen egoera (Eusko Jaurlaritza, 2020) lanean jasotzen duen bezala, errefrau eta esamolde biltzen aritu izan diren «hiru egileren artean (Damaso Intza, Aita Donostia eta Resurrección María Azkue), 177 emakumezko informatzaileen berri jaso ahal da. Orotara, 514 informatzaileen artean, $\% 34,43$ a direla adierazten du.» 
Euskal baladen eremua euskaraz hitz egiten zen eremu guztietara zabal daiteke (baita gaur egun euskara galdu den lurraldeetara ere). Horrela, euskalki ezberdinak agertu ohi dira baladetan. Joseba Lakarrak, Koldo Bigurik eta Blanka Urgellek 1983an argitaratutako antologian, horrela sailkatzen dira baladak euskalkiaren arabera: 11 bizkaieraz, 4 gipuzkeraz, 13 goi nafarrez, 9 lapurteraz, 10 behe nafarreraz eta 11 zubereraz (1983: 192). Balada batzuk, gainera, euskalki batean baino gehiagotan ageri dira (1983: 199).

Kontuan har bedi halaber euskalki eta baladen arteko erlazioak begiratzean ezen balada gai askok gure artean bost edo sei mende daramatzala eta orain dela bostehun edo hirurehun urte euskalkien arteko ezberdintasunak orain direnak baino askoz txikiagoak izateaz gainera, gaiek denbora guzti hori izan dutela lurralde gehiagotara hedatzen joateko eta euskalki ezberdinetara moldatzeko.

Hedapen kronologiko eta geografiko zabal honek bizi-iraupena eta bizitasuna adierazi lezake. Lan honek, hedapen hau desbirtualiza ez dadin, haien artean bai denboraz bai lekuz urrun kokatzen diren testuak aukeratu ditut.

Bestetik, azaldutako kontzeptuak hartuko dira kontuan. Tokian eta denboran testuen dispertsioa nabarmena izan arren, antzekotasunak aurki daitezke baladetan, bai alde formalean, bai kontzeptuetan edo eszenetan ere.

Lan honetan aztertzen diren testuetan, ondoren aipatuko diren alderdiak errepikatu egiten dira:

- Emakumearen ahotsa: guztiak dira emakume batek kantatuak, edo emakumearen ahotsa entzuten da.

- Emakumea, protagonista: bost balada hauek emakume baten istorioa kontatzen digute, bera delarik, zalantzarik gabe, protagonista.

- Ezkontza edota amodioa: guztietan ageri da ezkontza edo amodioaren ideia, batzuetan zeharka bada ere.

- Bortxa: guztietan agertzen da bortxaren ideia.

Ezaugarri hauek erabili dira, beraz, irizpide gisara, eta horietatik sor daiteke hainbat hipotesi. Abiapuntu hau hartuta, baladaz balada, forma eta ideiak aztertuko dira, elementu amankomun bila. Formari begira, Proppen (1977: 91) teoriak jarraituz, aktanteen papera aztertuko da eta egiturari ere erreparatuko zaio, errepikatzen diren patroiak ezagutzeko helburuarekin. Elkarrizketetan jarriko da arreta, ikuspegi arteko oposizioa islatu dezaketelakoan eta baladetan tentsio-gunea koka dezaketelakoan. Honetaz gain, ideiei begira, kontraesanetan jarriko da arreta, esan ezin denari erreparatuko zaio, agerikoa ez den errealitate bat dagoen aztertzeko, ezkutuko mezuak igorri diren argitzeko. Ikerkuntza honen helburua, galdera hauei erantzuna ematea da: forman antzekotasunik badago, ba al dago ideietan antzekotasunik? Honek adierazten al du badagoela errealitate bat luzez ezagun suertatu dena? Ulertzen al da oraindik errealitate hori? 


\section{III.- BALADEN AZTERKETA}

\section{A. Andre Emili}

Balada zaharrenetariko bat da; Humboldtek (1817) 1492an arabiarren kanporaketa baino lehenagokoa zela esaten bazuen ere, hau ezin da ziurtatu. Ezagutzen den Andre Emiliren eredurik zaharrena XVII. mendeko Oihenarten Art Poetique (1967, 205-229) lanak eman zuen ezagutzera, beraz, zalantza barik baiezta daiteke 1665 baino lehenagokoa dela. Antonio Zavalak (1996: 45-68) lau eredu baino ez zituen bildu, eta Jabier Kaltzakortak (2017: 67) beste bat jaso du. Balada laburra da; ezagutzen diren testu guztietan, Oihenart, Humboldt eta Azkuek bildutakoetan, hiru ahapaldi baino ez ditugu aurkitzen.

Lan honetarako, Humboldtek Lapurdin, Itsasun, 1801ean Harambillet apezari bildutako aldaera erabiliko da. Lapurtera da, beraz, erabilitakoa euskalkia.

Proppen (1977: 91) teorien arabera, hiru dira balada honetan gauzatzen diren akzio esferak:

- Printzesarena: Andre Emili, gure protagonista, da akzioa jasaten duena. Geroago ikusiko den moduan, narrazioan subjektua ere bada, akzioaren subjektu pasiboa da.

- Aurkariarena: aita eta ama dira aurkariak, Andre Emiliri kalte egiten diotenak. Hasiera batean senideak laguntzaileak izan zitezkeela pentsa badaiteke ere, beste hainbat baladetan bezala, hemen ez da honela gertatzen.

- Heroiarena: anaia txikia da "printzesa" (protagonista) etsaiengandik, hau da, mairuengandik (hauek ere aurkarien papera betetzen dute, bigarren plano batean) salbatzen duena.

Arestian esan den bezala, balada laburra da, hiru ahapalditakoa (sarrera, korapiloa eta amaiera).

Formalki, elkarrizketarik agertzen ez bada ere, bi ahots entzuten dira balada honetan, eta bi ahots narratiboen jarraipenak garrantzi handia hartzen du baladaren egituraketan.

Lehenengo ahapaldiak egoera aurkezten du, eta ezagutzen ez den pertsonaia baten ahotsa entzuten da; ez dago jakiterik narratzailea edo senideren baten ahotsa den. Bertan, protagonista aurkezten da: saldua izan den emakumea.

Bere izena ezaguna da, Emili, eta goi mailako andrea da lehenengo bertsoaren "andre gora" horrek adierazten duenez. Ez du balio, beraz, lan egiteko, ezin baitu artoa jorratu ez eta ogia oratu, bigarren eta hirugarren bertsoetan esaten den bezala. Egoera sozialak ez du ekiditen, ordea, menpekotasun egoera; eta, "zoaz Mairu herrin gora" aginduarekin, deskubritzen da lehenengo ahapaldiaren amaieran zein izango den dama honen patua. Esan daiteke, izan ere, agintera hori mespretxuz erabiltzen dela. Etxetik urrun bidalia 
izan denarentzat ez da itzul-biderik. Beraz, erbesteratze behartu baten amaiera da, agurrik eta errukirik gabea, bortxaren kontzeptua agerian uzten duena.

Esatariaren ahotsak protagonistarengana hurbiltzen du entzulea bigarren ahapaldiaz geroztik. Bigarren eta hirugarren ahapaldiak lehenengo pertsonan daude; protagonista da hitz egiten duena, bere istorioaren lekukotasuna emanez, pertsonaiari bere subjektu izaera emanez. Bigarren ahapaldian planteatzen da baladaren gakoa: goi mailako andrea izanagatik, saldu egin dute familiakoek eta mairu herrira bidali. Kontraste handia dago: alde batetik, beragatik zehatz mehatz zenbat ordaindu den, emakumearen hitzez, ezagun da: "ehun pizu dirutan eta berrehun dupa eztitan"; ez, baina, norengana bidali duten. Lehenengo ahapaldiaren erreferentzia oso pobrea da: "zoaz Mairu herrin gora", are gehiago beste balada batzuekin alderatuta (adibidez Atharratze jauregian edo Urrutiako anderea baladekin, zeinetan protagonisten izenak badakizkigun). Esan ote liteke, orduan, andre hori nora joan den jakiteak edota berari gertatuko zaiona jakiteak ez duela garrantzirik. Eta zein bilakabide izango duten emakume horren senideek saria jaso ondoren, ez al du axola? Ezer ez, ez dakigu ezer: baladak ez digu horri buruzko daturik ematen.

Hirugarren ahapaldian kokatzen da balada honen tragikotasun momenturik gorenena; singularreko lehenengo pertsonan jarraitzen du: «Aita nuen saltzaile, ama diruaren hartzaile». Etxeak segurtasuna suposatu beharko luke, eta familiak, kanpoan dauden arriskuengandik babesa. Tere Irastortzaren hitzetan (2004: 35), «Etxea balitz amodioaren bihotza, etxetik abiatuta neurtuko genituzke gerturatze-urruntze, ziurtasun-arrisku probabilitatea». Ez da horrela, aldiz, Andra Emilirentzat. Etxean bertan zituen erasotzaileak; gurasoak, hain zuzen, dira ezezagunei saldu behar zietenak, inporta barik bere suertea. Azken bertsoetan, berriz, itxaropenerako lekua dago, bere anaia txikiaren eskutik: « Anayric chipiena / Mairutaric kentzaile». Gogoratu behar da euskal tradizioan anaia txikiak ez zuela herentziara eskubiderik ${ }^{2}$. Ondasun trukaketa honen aparte egonda, mutila da bere arrebaz errukitzen dena eta «Mairutaric» (berriro erreferentzia zehatzik gabea) kentzen duena.

Familiakoen parte hartzearen berri eman ondoren, azken ahapaldian, protagonistaren ahotsaz gain, protagonistaren hausnarketa eta gogoa ageri dira. Lehen pertsona singularrekoak bere gogoetak eta sentipenak adierazten ditu, ez iada bere familiakoentzat, baizik eta bere buruarentzat eta, hein batean, entzuleriarentzat esanak. Eztabaida eta elkarrizketaren unea gainditu da, eta

2 En la franja rural atlántico-pirenaica, desde Galicia hasta Baleares, pasando por áreas de Asturias, Cantabria, País Vasco y norte de Navarra, Aragón y Cataluña, encontramos el modelo de la familia troncal, en el que el patrón de residencia es virilocal. Se caracteriza por la elección de un heredero (millorado, mayorazgo, etxekojaun, eredeu, hereu) que perpetúa el linaje y reside donde sus padres, llevándose con él a su mujer y su descendencia. La filiación, sucesión y herencia, de este modo, son patrilineales, y solo las mujeres que se van a casar con un heredero son dotadas. Normalmente, este patrón virilocal se aplica solo a los herederos, no a los segundones, varones o no, que deben afrontar la alternativa de casarse y vivir en otro lugar o permanecer solteros como fuerza productiva si desean continuar residiendo en la casa. (Ceballos, 2010: 33) 
subjektuarenak dira azken hitzak. Entzuleriaren enpatia bila bere arrazoia aldarrikatzeko momentua da.

\section{B. Frantziako anderea}

Euskaraz aldaera gehien dituen eredua da Frantziako anderea edo Frantzia kortekoa, 24 aldaeratik gora ez badoa ere. Nafarroan bildutako hiru izan ezik, beste guztiak Bizkaian bilduak dira (Markinan, Galdakaon, Arratian, Zeanurin, Diman...). Lan honetarako, Juan Manuel Etxebarriak 1999an Zeberio kantak (1999: 60) liburuan jaso zuen Zeberioko aldaera hautatu da, zeinetan bizkaiera erabiltzen den. Aldaera luzeena dugu hau, hogeita bat ahapaldi gorde baitira.

Proppen funtzioei eta pertsonaiei erreparatuz, hauexek dira agertzen direnak:

- Printzesa: Frantziako anderea dugu protagonista. Berak jasaten du aurkariek egindako gaiztakeria. Nahiz eta aurkarien kontra aritzen saiatzen den, ez da gai salba dezaten konbentzitzeko, eta hil egiten dute.

- Laguntzailea: Frantziako anderearen senarra eta bere amaren arteko elkarrizketa erakusten dute lehenengo bederatzi ahapaldiek. Senarra laguntzailearen esferan mugitzen da, bere amari aurre eginez, emaztearen bizitza salba nahian.

- Aurkariak: lehenengo momentutik amaginarreba agertzen da protagonistaren aurkari, semeari erahiltzeko agintzen baitio. Hamargarren ahapalditik aurrera, senarraren papera aldatzen da eta hau ere aurkari bilakatzen da.

Egituraren aldetik, banatze argi bat dago Frantziako anderean: lehenengo bederatzi ahapalditan, ama eta semearen arteko elkarrizketa; hamargarrenetik hogeita batgarrenera, senarra eta emaztearen artekoa. Lehenengo zatian, gaia aurkezten da: semeak Frantzian ezkondu izanaren berri ematen dio amari; amak, honen berri duenean, emaztea hiltzeko agintzen dio semeari. Bigarrenean, hilketa deskribatzen da eta, azken ahapaldian, neskak amaginarreba madarikatu egiten du.

Balada hau, beraz, amaginarreba gaiztoaren tradizioaren barruan koka daiteke, gai paneuropeoa delarik ${ }^{3}$ : erraina senarraren familiarekin bizitzera dator, eta emakume barri bat heltzearekin batera etxeko jokabide-ereduak aldatzen dira, etxeko lanak eta gizonarekiko lotura afektiboak ere eraldatuz. Horrek sortzen ditu tentsio egoerak, balada honetan ere. Ezkontza exogamiko hauek etekin argiak ekartzen ditu komunitatearentzat: ondasun materialaren hartu-emana (doteak edota emaztegaiaren prezio zehatza) eta komunitateen arteko elkartasun loturak.

3 Espaina, Ingalaterra, Eskozia, Eskandinavia, Finlandia, Frantzia, Italia, Errumania, Jugoslavia, Hungaria eta Greziako adibideak biltzen ditu Ignacio Ceballos bere El romancero tradicional y las relaciones de parentesco: la suegra malvada tesi lanean (Ceballos, 2010: 423-474). 
Hala ere, ezkontze exogamikoek badituzte desabantailak ere, hala nola patrimonioaren desintegrazioa; gainera, bere etxeko segurtasunetik urruntzera behartzeak, emaztearentzat arriskuak dakartza. Senarrarren etxera bizitzera joaten denean (birilokaltasuna), bere bizilekuan arrotz bihurtzen da emakume hau, amaginarrebaren menpe. Honek tentsio handia eragiten du, neskak bere jatorrizko familiaren laguntzarik ez duenez (Ceballos 2010: 21). Azter dezagun, beraz, Frantziako andereari gertatutakoa.

Lehenengo bederatzi ahapalditan, esan bezala, ama-seme arteko elkarrizketa ageri da. Ama sukaldean da, hots, etxeko bihotzean, etxeko arima balitz bezala. Erabiltzen diren epitetoak tristerik eta bakarrik dira; semeak amarekiko nolabaiteko enpatiaren irudia transmititu nahi du. Amak entzun du semea ezkondu behar dela, baina laugarren ahapaldian aurkitzen du dagoeneko ezkonduta dagoela («Ezkonduta nago ta / on dator andre»); beraz, semeak familiaren aginduak urratu ditu, ez baitu kontuan hartu zer lortu nahi zuen bere familiak ezkontzaren bidez. Horrek emazte berria arrisku bizian uzten du, arrotza izateaz gain, ez baita etxe berrian ongi etorria. Ama errukigabea da, eta bortizki esaten du egin-beharrekoa, agintera erabiliz: «ori il eizu eta / artu eizu bestea». Bosgarren ahapaldian erraina Frantziako kortetik datorren berria jasotzen du amaginarrebak ${ }^{4}$; jatorri noblea badu ere, atzerritar izaerak pisu handiagoa dauka eta horrela erantzuten dio amak semeari: «ez dot gura frantzesik, gitxiago erranik». Semeak, irmotasunez, oraindik eusten dio bere ezkontzeko erabakiari, eta amari aurre egiten dio: «esan dodan berbeaz / urten behar dot nik». Bi bertso hauek baladetan behin eta berriro azalduko zaigun gai bati egiten diote aipamen. Ezkondu arte, mutilak bere familiaren ohorea mantentzeko ardura izan du, eta ezkondu ondoren ere, bere hitza mantentzeko beharra azaltzen du. Zortzigarrena trantsizio ahapaldia da. Berriro esango du semeak ez duela hil nahi, baina oraingoan arrazoia bestelakoa da: neskaren edertasuna («Ain da polita ba ze / nire emaztea / ez da posible, ama, / nik ori eitea»). Argudio honek gizonaren indarra baino, semearen desioa (eta ahultasuna) erakusten du, orain arte bere autoritateari eusten saiatu zaion gizona berriro semearen paperera itzultzen delarik. Balantza, beraz, jatorrizko familiaren aldera jausi da, eta argi geratzen da ohorea amari zor diola. Irtenbidea, beraz, argi dago: bere emaztea hil egin behar du, anaia gazteak lagunduta, amaren aginpidea jarraituz.

Ondorengo eszenak ezkonberrien arteko elkarrizketa antolatzen du. Lehengo pertsonan mintzo den emazte ezkonberria da subjektua, uste gabeko egoerari aurre egiten diona. Deigarria da senarra eta koinatuaren errukigabetasuna. Neska saiatzen da bide guztiak erabiltzen bere bizitza salbatzeko, eta aberastasun handiak eskaintzen dizkie salba dezaten ( Aixek emongotzudaz / ixtearen bizirik» eta «Danak emongotsudaz / itxi ni bizirik»). Hala ere, gaiztakeria handiz, horrela erantzuten dio senarrak birritan: «arek neuretzat baina / ez itxi bizirik» eta «dana neutzako baina / ez itxi bizirik».

\footnotetext{
4 Atharratze jauregian bezala, hasierako egoera Frantziako noble bat Espainara ezkondu delako ematen da.
} 
Frantziatik zetorrela zeuzkan usteak galdu ditu emazte ezkonberriak hitz hauek entzunda. Hamaseigarren ahapalditik aurrera, emazte ezkonberria jabetzen da sortu den egoeraz. Amaieraren hasiera antzematen du. Ohoreaz hausnartzen da hamaseigarren ahapaldian: Frantziako nebez akordatzen da, haiek mendekua hartuko luketela pentsatzen du gertatzen ari dena jakin izango balute. Baina ez da horrela izango: neska galdua dago, eta horrela azalduko da hamazortzigarren ahapaldian: «kanpai bat entzuten dot ez dakit nongoa». Kanpaiak egunerokotasunean zeuden sartuta balada sortu zen aroan, eta munduan kokatzeko tresna ezin hobea ziren. Kanpaiena tradizio handiko motiboa (Ceballos 2010: 237) da eta, artikulu honetan, Atharratze jauregianen ere agertuko dira.

[...] un elemento sobrenatural topificado en el romancero: el de las campanas que tocan por sí solas anunciando la muerte del bienaventurado, como si milagrosamente testimoniaran la inocencia de la nuera y clamaran por la injusticia que se ha cometido.

Hala ere, protagonistak, kanpaiak entzutean, ez daki nongo kanpaiak diren, ez daki non dagoen. Ez dago bere etxean: atzerrian dago, aurreko balada aztertzean komentatu den bezala, inor ez balitz bezala.

Tragikotasuna areagotzen du odolez betetako izararen irudiak. Kanpaiak entzutean desorientatuta agertu den ezkonberriak ezin du ezer onik itxaron odoldutako izararen aurrean.

Azken babes edo helduleku baten bila, abadea eskatzen du ezkonberriak konfesa dezan («abadea ekasu / konfesa naiten / arimaren okerrak / arteztu daidazen»), baina mespretxuz erantzungo dio honela senarrak: «Abadea urrin dago / eleiza urrinago; / oin orretan asteko / asti gitxi dago». Kontuan hartuta garaiko pentsamoldeak, konfesioa ukatzea krimenik gogorren bihur daiteke, mundu honetako bizitza ukatzeaz gain bestekoa ere ukatzen baitio.

Ezkonberrien arteko elkarrizketan, beraz, agerian dago bien artean gizarte rolen arrakala: senarra engainatzaile eta krudel bihurtzen den bitartean, emaztea bizitzari eusteko gai ez den biktima dirudi. Hala ere, lehenengo partean ahotsik izan ez duen neska honek eskaintzen ditu, berriz, indar handiko bi parte hartze. Lehenengoa, hamaseigarren ahapaldian, zeinetan Frantzian dituen zazpi nebez oroitzen den azken arnasa ematean; berriro ere, lehen aipatu den moduan, hilzorian gomutarako tartea agertzen da, etxekoak oroitzeko eta maite dutenez gogoratzeko lekua. Bigarrena, azken ahapaldian, amaginarreba madarikatzen duenean, aztertutako baladen artean honelako amaiera bakarra delarik, nahiz eta badagoen horrelako kasu gehiago euskal baladetan. Azken ahapaldi honetan, bere bizitza galduta sentitu arren, bere heriotzaren aurrean indartsu agertzen da, eta, madarikazioaren bidez, bere etsaien bizitzan esku hartzen du. Bere autoritateari eusteko gai izan ez den senarrarekin alderatuta, emakume ausarta da, aberastasunak eskainiz boterearen argudioa erabiltzen dudarik ez duena eta amaiera arte bizitzari eusteko asmo irmoa duena. 


\section{Urrutiako anderea}

Euskal jatorriko balada hau balada historikoen ale preziatuenetakoa da, etxe-izen ezagunetako protagonistak baititu: Nafarroa Beheko Baigorriko Etxuauzeko andrea eta Zuberoako Altzürükü herriko Urrutia etxeko jauna (Kaltzakorta 2017: 341). Jean de Jaurgainek aztertu zuen lehenengoz «Quelques légendes poétiques du Pays de Soule» (1899: 359) lanean. Chaoren kantutegian ere jasoa izan zen, eta Jean Haritschelhar lehenengoz transkribatu zuen 1963an Gure Herria aldizkarian (1963: 243). Balada zaharra da, 1656 baino lehenagokoa, Oihenarten 1657an Les proverbes basques recueillis par le s. d'Oihenart liburuaren atsotitz batek zazpigarren ahapaldiaren bertso bat errepikatzen baitu. Zuberera erabiltzen da aldaera honetan.

Balada honetan ere, hiru izango dira Proppen teorien araberako azaltzen diren akzio esferak. Beste behin ere:

- Printzesarena: Urrutiako damak jasaten du akzioa, kaltea.

- Aurkariak: Musde Urrutia eta Jaun Erretora dira Urrutiako anderea gaizki tratatzen dutenak.

- Laguntzailea: Etxauzeko bizkundiak, hots, Urrutiako anderearen nebak, salbatzen du protagonista.

Aurreko bietan bezala, goi mailako andrea da baladaren protagonista: Etxauseko andrea, Garatian Agerrian hazi zena, Baionan eskolatua izan zena (garai horretan bere mailako beste emakume asko bezala, ikasia zen). Lehenengo pertsonan dago idatzita balada hau, Etxauseko andrea subjektu bihurtzen delarik bere testigantza emanez. Ez dago, beraz, elkarrizketarik; protagonista entzuleei zuzentzen zaie berari gertatutakoaren berri emateko helburuarekin.

Egiturari dagokionez, hiru zatitan bana daiteke balada: lehenengoan, lehenengo ahapalditik seigarrenera, gaia aurkezten da (andereak bere burua aurkezten du eta bizi duen egoera salatzen du); bigarrenean, seigarren ahapaldian, aurreko kasuetan bezala bere sorlekua eta maite dutenak oroitzen ditu; hirugarrenean, zazpigarrenetik bederatzigarrenera, irtenbidea agertzen da.

Aipatu legez, lekuek garrantzi handia izango dute balada honetan. Azter dezagun bigarren ahapaldia: antitesia dela medio, Altzürükü Urrutia «lekhü famatia» da bigarren bertsoan eta «phenaz hiltzeko lekhia» laugarrenean. Honek markatzen du baladaren erritmoa: alde batetik aberastasuna eta ospea, bestetik tratu txarrak. Gaiaren sarrerarekin jarraituz, eta berriro ere kontrastearen bidez, Urrutiako jauna eta herriko erretorea inozentziarekin lotutako ezaugarriekin aurkezten dira (kolore argiekin, hain zuzen); errealitatea, berriz, bestelakoa da, eta hirugarren ahapaldiaren azken bi bertsoetan argi geratzen zaigu: «haiek biek ni narabila / Ürrütian ezteiari». Laugarren eta bosgarren ahapaldietan azaltzen da, hitzerdika ibili gabe, zein den, protagonistaren egoera.

Etxe barruan kokatzen da akzioa, eszenaka. Gure andrea etxean gordeta dago, sukaldetik gelara eta gelatik sukaldera (enfasia ematen zaio honi 
errepikapenaren bidez). Kexa garbiago azaltzen da protagonistak deskribatzen duenean zelan heltzen dioten ileetatik bere erasotzaileek: «Kosinati khanberala / khanberati kosinala / hiruretan üngürarazi zeitan / bilho-adatsa eskietan». Honi adulterioa gehitzen zaio: «murde d'Ürrüti ez zen ageri / ene tela mihisetan / nahixago beitzüen / amuren kapitetan».

Seigarren ahapaldian dramatismoa da nagusi. Aurretik esan den bezala, balada honetan ere protagonistak bere sorlekua gogoratzen du, herriaren izena (Baigorri) «maite» epitetoarekin lagunduz. Han «harriak ere alde» izango zituela esaten du; harriak bihozgabeak eta hotzak badira ere, senarra eta erretorea bihozgabeagoak eta hotzagoak dira. Beste behin ere, jasan dezakeen indarkeria maila gehiegizkoa denean, eta irtenbiderik ikusten ez duenean, protagonistak etxea, familia izango du gogoan, «hilik ere» maite duten lekura itzultzeko desioa adieraziz.

Zazpigarren ahapalditik ohoreak hartzen du berriro ere garrantzia, emazteak bere nebari leporatzen dionean arreba ahaztuta izatea eta bere ohoreagatik tratu txarren biktima izatetik ez salbatzea. Neba («Etxauzeko bizkundia») bere posizioari dagokion bezala arranditsu abiatzen da andrea salbatzera. Urrutiako jauna leihotik eskapatzen da, zeukan duintasun apurra galduz («Bizkundia armatürik / zaldi urdina zelatürik / Ürrutian sarthü züzün / Ürrütia eskapi lehiotik»).

\section{Neska ontziratua}

Brodatzen ari nintzen bezala ezagutua ere, tradizio handiko balada da, Europa osoan zabaldua (Kaltzakorta 2017: I, 561). Barbierrek eta Dufauk (19211926) argitaratutako Gure Herrian Lapurdiko (Senpereko) eredua bakarrik ezagutzen bazen ere, geroztik beste hainbat eredu jaso dira. Neska ontziratua izendatu zuen lehenengoa Santi Onaindia izan zen, bere Milla euskal-olerki eder liburuan (1954). 80. hamarkadatik hona Bizkaian beste hainbat eredu ere jaso zen: Foruan, Bermeon, Diman eta Zamudio-Derion (Kaltzakorta 2017: I, 656585 eta 2017: 109). Ikerkuntza lan honetarako, Donibane Garaziko aldaera aukeratu da. Eredu hau Jabier Kaltzakortak finkatu du, Pierre Duny-Pétré idazlearen paperen artean aurkitutako xix. mende bukaerako edo xx. mende hasierako dokumentu idatzi batetik jasoa (2017: I, 603). Behe-nafarrera da erabiltzen duen euskalkia.

Proppen eskemak jarraituta, hauek dira azaltzen diren akzio-esferak:

- Printzesarena: hainbat funtzio beteko du pertsonaia honek. Etxetik urruntzen da gizarteko debeku bat urratuz, ustekabean engainatzen du ustez laguntzailea zen aurkariari lagunduz eta kaltetu bihurtzen da; azkenean, engainatuta, bere buruaz beste egiten du.

- Aurkariena: balada honetan aurkari argi bat eta ezkututako aurkari bat daude. Marinela da printzesaren aurkaria, sedukzioaren bidez bere etxetik urrunarazten du eta urrun dagoela, bortxatu ondoren, aurkariaren sablearekin bere buruaz beste eginarazten dio (kaltea burutuz, hain 
zuzen). Neskaren amak ere aurkari legez jokatzen du, neska lagundu barik aurkariarengana bidaltzen baitu, kaltea ahalbideratuz.

- Laguntzaileak: marinelak dira, gero neskaren gorpuaz arduratuko direnak.

Elkarrizketak pertsonaia ezberdinen artean gauzatzen dira: neska eta amaren artean hirugarren eta laugarren ahapalditan; neska eta kapitainaren artean bosgarren eta seigarren ahapalditan, eta hamargarrenetik hamahirugarrenera; kapitaina eta marinelen artean zortzigarren, bederatzigarren eta hamalaugarren ahapalditan. Honetaz gain, protagonistak lehenengo pertsonan hitz egiten du lehenengo eta bigarren ahapalditan, narratzailea zazpigarren ahapaldian eta hamargarrenaren lehenengo bertsoan agertu arren.

Egituraren aldetik, lehenengo bi ahapaldiek sarrera gisa funtzionatzen dute; korapiloa, hirugarren eta hamabigarren arteko ahapalditan ageri da; irtenbidea, hamahirugarren eta hamalaugarrenean. Hamabosgarren ahapaldian, aurreko baladetan legez, hausnarketarako eta gomutarako tartea dago.

Lehenengo momentutik, lehenengo eta bigarren ahapalditan, ematen dio hasiera neskatilak akzioari. Bera da bere istorioa kontatzen duena, subjektua, eta horretarako lehenengo pertsona erabiltzen du. Ez da aipatzen jauregirik, baina «sala batian brodatzen» kokatzen da protagonista; handi-etxe bati buruz ari da, beraz. Aurrerago ematen den amaiera ikusita, neskatila, salan egon arren, ez zegoen oso ondo gordeta. Interpreta liteke zuhurtziagabetasunez jokatzen dutela bai amak bai alabak hurrengo ahapaldietan: alabak amari itsaso bazterrera joateko baimena eskatzen dio eta hark, nahiz eta «iluna dela hurbildia» eta «gibelerat itzultzea» esaten dion, baimena emateaz gain etxera etortzera gonbidatzen du marinela («Habil eta erran zakon jin dadin gure etxerat / jin dadin gure etxera eta gurekin afaltzerat»). Hau da, etxe barruraino sartzeko baimena ematen dio ezezagun bati; Tere Irastortzaren (2004: 42) hitzetan: «Sartzen da inor etxera? Gehienetan atarian gelditzen dira maitaleak eta, sarri, elkarrizketa izan ohi da sarbidea ez emateko bidea» (eta balada ez da maitaleaz ari, ezezagun bati buruz baizik).

Itsaso bazterrera abiatzen da, beraz, gure protagonista. Puntu honetan ikusgai daude tragikotasunerako elementu guztiak: etxeko zuhurtasuna uztea eta itsaso bazterrera abiatzea, (itsasoak muga, arriskua eta urruntasuna suposatzen duelarik $^{5}$ ) eta ezezagun batengana zuzentzea.

Mandatu honekin, neskatilak marinelari honela esaten dio: «Aitak eta amak igortzen naute jin ziten gure etxera». Neskaren inozentzia erakusten du bertso honek, ez baita neskatilaren nahia etxera joatea gizona, gurasoena baizik. Tolesgabetasun hau dela medio, engainua burutzea ez da zaila, eta marinelak ez du asko behar neskatila itsasontzira igotzera konbentzitzeko («sar zaite sala huntan barnerat, andereoren pollita / hemen erakutsiren dauzkizut koblekilan airia.»). Kapitainak «sala huntan barnerat» sartzeko eskatzen dio, besteen

\footnotetext{
5 Honi buruz adibide ugari dago, hala nola Lo hadi aingürüa lo-kanta, Bermioko Badatoz eskultura edo Galizian «loito de vivos» ohitura, Rosalía de Castrok Follas novasen aipatzen duena.
} 
bistatik aparte, traizioa burutzeko: marinela lo-belarra jartzen dio lokar dadin eta itsaso barrenera eramaten du. Laguntzaileak, hau da, marinelak, saiatzen dira neskari laguntzen. Honen arrazoia neskatilaren edertasunean (bere inozentziaren sinboloa delarik) datza («Andere lerden, pollit hori behar duzia tronpatu?»).

Neskatilak itzartzen denean eta bere egoeraz ohartzen denean etxera itzultzeko eskatzen dio marinelari agindu baten bidez, «Turna nazazie, turna, hartu nuzien lekura», baina honek bostehun legua horiek distantzia luzeegia direla erantzuten dio. Berriro ere agertzen da urruntasunaren kontzeptua; neska galdua dago itsasoaren erdian bere bahitzailearen esku, etxetik, hamaikagarren ahapaldian aipatzen den ama eta aitaren portu horrengandik, urrunegi. Baladak aipatzen ez badu ere, gizonak neskatila bortxatu izanaren seinaleak argiak dira; izan ere, hamabigarren ahapaldian dendaria madarikatzen du, gona txikiegia izanagatik ( «Zeren baieraut egine zaiaren zola her[t]xixe / zaiaren zola hert[x]ixe eta gerruntzian tinkixe»). Bertso hauen errepikapenak neskaren antsietatea erakusten du; ez da argi geratzen, baina, gona estu izatea, metaforarekin jarraituz, neska jasaten ari den estualdiaren ala haurdunaldi baten ondorioa den.

Amaiera ezin bestelakoa izan, neskatilak bere ohorea zikinduta ikusi baino lehen nahiago du bere burua hil eta, aiztorik ezean, ezpata eskatzen dio kapitainari eta bihotzean sartzen du. Ezpata bezain zorrotz, bertso bakar batean ebazten da trama, narratzailearen ahoz: «Hartu zuen eskurat eta sartu zuen bihotzetik.».

Kapitainak desesperazioa erakusten du hamalaugarren ahapaldian, Jaungoikoaren beldur, neska hil eta ehortzi ezinean. Marinelak, berriro ere, neskaren alde agertzen dira, etxera itzul dadin aukera emanez: «Emozu bi musu eta aurtikazu itsasorat / itsasorat eremenen dau, bere aita-amen porturat». Balada honen kasuan ere, hil-ondoko gogoeta agertzen da, aita eta amarengana, hots, maite izan dutenengana, joateko desioa.

Azken ahapaldiak gure subkontzienteari deitzen dio, oso irudi grafikoa eskainiz: itsasoa handia eta arriskutsua da, «Itsasoan hura lodi, zolarik ez du ageri»; bere uretan murgiltzera ausartzen denak neskatilak bezala bukatuko du: «ene maitea hantxet dabila arraina bezala igeri».

\section{E. Atharratze Jauregian}

Balada-gai oso aztertua da Atharratze jauregian; 1899an Jean de Jaurgainek «Quelques légendes poétiques de Pays de Soule» (1899: 359) artikulua eskaini zionetik, asko izan dira balada hau aztertzen aritu direnak, 1999ko JeanBaptiste Orpustan (1999: IV, 57-79) eta 2010eko Jesús Antonio Ciden (2010: 11 eta 36-62) lanak aipatu behar direlarik. Azken honek, balada honen eredu asko biltzen ditu «Re-deconstruyendo la balada: Atharratze jauregian» artikuluan. Artikulu honetarako, Chaoren lehen eredua aukeratu da, Arxüren eskutikoa jasoa dena eta Kaltzakortak (2017: I, 133) jasotzen duena. Zuberera erabiltzen da aldaera honetan. Kronologia buruz, 1587an Charles de Luxe eta María de Ossés ezkontzaz eta Nafarroara erbesteaz ari dela pentsatu bada ere, Antonio Cidek (2010: 170) hau deuseztatzen du: 
La balada no se compuso en 1584, ni entre 1587 y 1593, como eco de distintas vicisitudes del caso histórico de la boda y posterior exilio de Charles de Luxe-Tardets y una Marie de Jaurgain, de Ossés (tesis de Jaurgain, aceptada por Guerra, Gorostiaga, Irigaray, etc.). Desconocemos la fecha en que se compuso Atharratze jauregian, y no puede asegurarse que sea de época medieval.

Proppen teorien eskema jarraituta, aurreko baladen antzerako eskema agertzen da, pertsonaiak hauek izango direlarik:

- Printzesa: balada honen protagonistak betetzen du printzesaren rola, beste pertsonaia guztiak bere inguruan mugitzen direlarik.

- Aurkariak: aurkari nagusia aita da, protagonista traizionatu duena. Birritan zuzentzen da neska aitarengana hau leporatuz, bigarren eta laugarren ahapalditan. Honen ondoan, Ongriagarayko jauna, neskaren senargaia, agertzen da, nahiz eta, aurrerago azalduko den bezala, pertsonaia baino, leku bezala uler daitekeen.

- Laguntzaileak: protagonista eta bere ahizparen arteko konplizitatea ageri dago lehenengo bertsotik, biak baitira aipatzen diren «zitroin doratü»ak. Berak eskaintzen dio babes emozionala eta konfiantza. Ahizparen papera sakonago aztertuz gero, protagonista ezkontzara bultzatzen duela ere ikusten da, aurkaritzat ere har daitekeelarik.

Ahizpaz gain, bigarren ahapaldian aipatzen da ama balizko laguntzaile bezala, bizirik balego alaba salbatuko zukeena. Hala ere, aukera hori ez da egiazkoa, ez baitago bizirik.

Hirugarren pertsonaia bat aipatu behar da: Atharratzeko Sala, neskaren beste ezkongaia, nahiz eta, Ongriagarayko jaunarekin gertatzen den bezala, lekuaren pertsonifikazioa izan daitekeen.

Egiturari erreparatuz, lehenengo eta azken ahapaldietan narratzailearen ahotsa entzuten den bitartean, tarteko lau ahapalditan protagonista eta ahizparen arteko elkarrizketa ageri da. Baladaren eredu honetan, narratzailearen partehartzeek gaiaren sarrera eta irtenbidea ematen digute, korapiloa ahizpen arteko elkarrizketaren bidez ematen delarik.

Beste behin ere, ezkontza exogamikoaren gaia azaltzen da. Lehenengo bertsoak neska biak aipatzen ditu metafora baten bidez: «bi zitroin doratü» (berriro ere nesken arteko elkartrukagarritasunaren ideia agertzen da, Frantziako anderean agertzen zen bezala). Neska eskatzen duena Ongriagarayko jauna da. Ongriagaray izenak hainbat datu ematen digu. Batetik, Ongriatik (Hungaria) dator senargaia; Hungaria urrun dagoen leku mitikoa da (Cid 2010: 166), hegoaldean, hain zuzen. Hau horrela izanda, Frantzia eta Espainiaren arteko konfliktoan koka daiteke balada hau, Frantziako anderean gertatzen zen bezala. Bestetik, garay atzizkiak atzerriko senargaiak jatorri noblea duela adierazten du. Hirugarren eta laugarren bertsotan, aitak alaba bat agintzen dio senargaiari.

Bigarren ahapaldian protagonistaren ahotsa lehenengo pertsonan entzuten da. Aitari kexaz agertzen zaio animalia balitz bezala saldu izanagatik, eta ama 
gogoratzen du, bere ustean berak atzerrira ezkontza hau galaraziko lukeelako. Ahapaldi honek, beraz, aurreko baladetan bezala ageri den moduan, maite izan duten pertsonak gogoan izateko espazioa agertzen da. Espainia eta etxea kontrajartzen dira eta, Atharratzeko Sala pertsonaia bezala agertzen den arren. Antonio Cidek (2010: 174) honela adierazten du:

Dado que en la balada la dialéctica real y significativa se establece entre dos “casas" y linajes situados en espacios geográficos distintos, y más especificamente entre virilocalidad y uxorilocalidad matrimonial, resulta obvio que en "Sala" lo esencial es también la casa noble y no la persona concreta que, circunstancialmente, la encarna. [...] Mi hipótesis es, en suma, que originariamente en la balada el término 'Sala' no tenía valores polisémicos y se refería unívocamente a la casa noble, la mansión o Sala de Tardets y su linaje; y que en esta estrofa, como en la anterior no existe en principio mención ninguna de un presunto amante o pretendiente individual de nombre 'Sala' que haya que oponer al prometido exógamo. La verdadera oposición es la que se establece entre Sala (Tardets) y el mundo exterior representado por 'España'o 'Hungría'.

Hirugarren ahapaldian ahizpa da protagonistari zuzentzen zaiona, senargaia heldu izanaren berri emateko («Ingoitik hor heldü da zure senhargeia»). Ezkontza saihestezintzat jotzen da, eta ahizpak «botzez» sortetxea uzteko aholkua ematen dio. Ahizpa lagun mina agertzen den balada honetan, deigarria da, tragikotasuna nagusi denean, ahizpak etxea «pozez» uzteko aginte hau, are gehiago laugarren ahapaldian protagonistaren ahotsez hau entzuten denean: «etxerat jinen zira xagrin handirekin / bihotza kargatuia, begiak buztirik, / eta zure alhaba thonban ezarririk.». Kontrastean jartzen da gainera lehenengo bertsoaren «joanen gira oro elgarrekin» eta bigarrenaren «jinen xira»ren singularreko bigarren pertsonan aitari zuzendua, eta neska bien elkartasunaren ideia indartzen du. Etorkizuneko denborak zalantzan jartzen du istorioaren garapena, ez baitakigu ezkontza gauzatu zen ala neska Atharratzeko jauregian bertan hiltzen den; honek ez du, hala ere, kontzeptu sakonean eraginik, ezkontza exogamikoak neskaren amaiera tristea suposatzen baitu.

Bosgarren ahapaldian neskaren destinoa jartzen da kolokan, haizearen esku utziz norekin ezkonduko den. Kontrastearen ideiarekin jarraituz, iparra eta hegoa aurrez aurre agertzen dira, iparra Atharratzeko ezkongaia (Frantziakoa) eta hegoa Ongriagaraykoa (Espainakoa) direlarik. Horrela esaten dio neskak ahizpari: «Ahizpa, zoaz orai salako leihora», etxearen garrantzia azpimarratzen delarik. Ahapaldi honen azken bertsoan, neskaren nahia argi azaltzen da, hego haizea egonez gero horrela esaten baitio ahizpari: «ene txerka jin dadila sarri», gorputzaren bila etortzeko agintzen baitio kanpotik datorren senargaiari.

Azken ahapaldian narratzailearen ahotsa entzuten da berriro. Neskaren amaieraren berri ematen da bertan:

Lo esencial para el significado son los signos présagos, ominosos, que refuerzan lo ya anunciado en la estrofa anterior: la próxima muerte de la dama. Las campanas que tocan solas, como los cirios que se encienden por sí mismos en la iglesia, son un lugar común en el folclore,como signo que indica la muerte 
de un bienaventurado que asciende a los cielos. Otro presagio más evidente es el luto que visten todos los habitantes, o sólo los jóvenes, de Tardets. ( Cid, 2010: 19)

Ez da argi geratzen, lehen aipatu den bezala, bidaia benetan ematen den ala bidaia metaforikoa den (hau da, atzerrira ezkontzen den neska ala ezkontza baino lehen Atharratzen bere buruaz beste egiten duen), baina honek ez du eragozten baladaren mezua igortzea.

\section{IV.- ONDORIAK}

Euskal baladen munduan murgiltzean, argi azaltzen da askoren arteko lotura sendoa, bai formala, bai ideologikoa.

Aztertutako balada guztietan ageri diren harreman guztiak familiaeremuaren ardatzarekin lotuta daude. Alde batetik, harreman heterosexual baten berri ematen dute guztiek; ezkontzarekin lotzen dira, eta baladetako protagonistek ez dute hautatutako amodiozko erlazioei buruz hitz egiten. Bestalde, kronologikoki garaiak desberdinak izan arren, guztietan bortxa jasaten duten emakumezkoen adina berdina da, direla ezkonberri, direla familiarekin bizitzetik bikotearekin bizitzera pasa direnak. Marko ideologikoa bihurtzen da, nolabait, bortxa-eragile.

Formari erreparatuz, aztertutako bost baladetan subjektu protagonikoa emakumezkoa da, lehenengo pertsonan hitz egiten duena. Bost emakumeren ahotsean gauzatzen da bere istorioa kontatzeko ardura, bere burua eremu publikoan kokatuz naturaltasunez. Lehen pertsonan hitz egiteak zera adierazten $\mathrm{du}$ : bere buruaren jabe izatea, bere bizitzaren protagonista izatea. Eta protagonismo hori adierazten dute balada kantatzen duten emakumezkoek, emakumezkoak isilik eta etxean menpe nahi zituen gizartean. Arestian aipatu den bezala, baladen kasuan performanceak berebiziko garrantzia dauka:

Performance significa competencia. Más allá de un saber-hacer y de un saber-decir, la performance manifiesta un saber-estar en la duración y en el espacio. Sea lo que evoque por medios lingüísticos el texto dicho o cantado, la performance le impone un referente global que es el orden del cuerpo. Es por el cuerpo por lo que estamos en el tiempo y el espacio: la voz, esa emanación nuestra, lo proclama. [...] Por eso, la performance es también una instancia de simbolización: de integración de nuestra relatividad corporal en la armonía cósmica significada por la voz; de integración de la multiplicidad de los cambios semánticos en la unicidad de la presencia. (Zumthor 1983: 157)

Ahotsak espazioa eta denbora bereak egiten ditu, eta ahotsaren bidez gorpuzten da mezua; testuetan lehenengo pertsonaren bidez islatzen denak, plazan gorputzaren bidez egiten du: beregain dira emakume hauek espazio publikoan. 
Zein da, baina, igortzen den mezua? Proppen eskemak erabiliz egindako azterketek laguntzaile eta aurkari banaketa oso berezia ematen dute. Lan honen aurretik, Iñarra Garcíak ondorioztatua zuen Azkueren eta Barandiaranen lanen inguruko ikerketa lanetan $(1994,8)$ :

Guk aztertzen dugun erasotzailea ez dator bat Propp-ek erabiltzen zuen kontzeptuarekin. Egile errusiarrarentzat, ipuin miresgarrien zazpi pertsonaien artean, hari dagokion egintzaren arloa gaiztakeria eta borrokarena izan ohi da, betiere heroia aurkaria izanik. Gure ikuspegitik, hiltzailea erasotzailea dugu, baina hau anti-heroia, heroia, edo beste pertsonaiaren bat izan daiteke, egileak bete behar duen baldintza bakarra hiltzea da, asmo hori izatea edo heriotzaz mehatxatzea.

Aktanteen egitekoak eta egoerak aldakorrak dira baladetan. Eta eraldaketa horiek tentsioa eragiten dute, bai tentsio dialektikoa (elkarrizketa), eta baita sinbolikoa ere (kanpaiak, zaldiak, eguraldia...).

Aztertutako balada guztietan, protagonistaren rola aldatuz doa. Lehenengo momentuan biktima irudia eman arren, egoera aldatzeko borroka egiten dute protagonistek. Andre Emiliren kasuan, bigarren ahapaldian neskak egoera onartzen duela ematen badu ere (berak azaltzen baititu egindako transakzio horren xehetasunak), azken ahapaldian patu horren aurka asaldatu dela adierazten du, lortu baitu bere nebak «Mairutaric» kentzea. Frantziako anderea baladan, ezkonberrien arteko elkarrizketan (hamabigarren eta hamabosgarren arteko ahapaldietan) emazteak, bere bizitza salbatzeko borrokaren testuinguruan, ez dauka bere senarrari aberastasunak eskaintzeko zalantzarik. Horrela, biktima irudia izan arren, emazteak senarra garaitu egiten du, esaten dionean berarekin geratuz gero izango litzatekeela, izan, boteretsu, aberastasuna dakarrena emaztea denez, senarrak ez lukeela familiaren beharrik boteretsu eta aberats bizitzeko. Urrutiako anderea baladaren lehen erdian, protagonistak jasandako kaltearen deskribapena egiten du, egoera kokatuz eta indarkeriaren xehetasunak emanez. Seigarren ahapaldira arte, beraz, biktimatzat aurkezten da protagonista. Baina seigarren ahapaldian aldaketa burutzen da, protagonistak adierazten duenean ez duela onartu nahi bere patua. Horregatik, zazpigarren ahapaldian, daukan arma erabiltzen du eta jatorrizko familia deitzen du salba dezan, bizi duen egoera eraldatzeko borroka eginez. Neska ontziratuaren kasuan, bahitutako neskatilak, bere egoeraz ohartzen denean, etxera itzultzeko eskatzen dio kapitainari. Beste behin ere, kapitainak errez engainatu duen eta, beraz, ahul ikusten dugun neskatilak, ez du onartzen egokitu zaion egoera, eta honen kontra borrokatzen du. Itzulera hori ere deuseztatua ikusten duenean, ausardi handiz eskatzen dio kapitainari arma eta bihotzean sartzen du. Protagonistak ez du onartzen erabil dezaten, kapitainaren nahia bertan behera galarazteko bere buruaz beste egitea hobetsiz. Amaitzeko, Atharratze jauregian izan daiteke kasu argiena: protagonista, agertzen diren beste pertsonaia guztien aurka, balada osoan zehar bere egoera aldatzen saiatzen da. Balada honetan bakarrik ageri da, aztertutakoen artean, beste senargai bat, eta bosgarren ahapaldian patuaren esku (haizea honen sinboloa delarik) uzten du batekin zein bestearekin ezkontzea. Protagonista biktima gisa aurkezten bada, 
eta atzerrira ezkontzea ziurtzat jotzen bada ere, neskak ez du hau onartzen eta azken momentura arte etxetik bidaltze hori ekiditen saiatzen da.

Aztertutako balada guztietan, lehenengo momentuan kanpo begirada batek biktima bezala erakutsi arren, protagonistak egoera hori aldatzeko borroka egiten du. Biktimak, galtzaileak, erasotuak ez du bere burua kokilduta erakusten, eta irabazle bihurtuko duen egoera berria irudikatzen du bere gogoeta bidez, jendaurrean. Horregatik, guztietan (normalean amaieretan) gogoetarako unera iristen dira baladak, eta bertan emakume hauek, beraien burua galduta ikusten dutenean, azken momentuko oroitzapen une bat dute babesa emango zietenak edo maite dituztenak gogoratzeko. Hausnarketa eta gomuta tarte hauek kontzientzia eremu bat zabaltzen dute, sarri heriotzaren ondorengo kontzientzia bat. Hilzorian edota hil ondoren beste aukera bat eskatzen dute, beraz: maite dutenengana itzuli nahi dute, fisikoki ezinezkoa bada ere, kantuaren bidez. Eztabaida eta elkarrizketaren unea gainditu da, eta subjektuarenak dira, beraz, azken hitzak, bere zuzentasuna aldarrikatzeko balio dutenak. Protagonistek, gogoeta hauen bidez, entzuten ari direnengan beraiekiko enpatia sortu nahi dute. Ikus dezagun zelan adierazten den kasu bakoitzean.

Andre Emili protagonista azken ahapaldian gogor ari da gurasoen kontra; zuzen salatzen ditu gurasoak, ez du zalantzarako tarterik uzten. Neba du gogoan azken hitzetan, maite izan duen pertsonaia bakarra, berak sentitu duen moduan entzuleriari ere enpatia helarazi nahian.

Frantziako anderea, bere burua galduta ikusi orduko akordatzen da Frantzian dituen nebez. Bere istorioaren amaiera argi dagoenean, maite dutenek burutu den gaiztakeria ulertuko zutela eta mendekua hartuko zutela adierazten du subjektuak, berak arrazoia duela aldarrikatuz. Gainera, azken ahapaldian, amaginarreba madarikatzen du protagonistak; beraz, hil ostean, besteen bizitza eragoztea du helburu, mundu honetan ezinezko duena beste munduan ere zuzena izango dela azpimarratuz bezala.

Urrutiako anderea baladaren erdian kokatzen da gogoeta ahapaldia, oraindik amaiera zein den ebatzi ez den arren. Oso argi adierazten da kasu honetan hil ondoko etxera edo maite dutenengana itzultzeko desioa eta enpatia nahia: «Ala Baigorri, Baigorri maite, / nik hilik ere, / hara nahi nüke. / Han harriak ere althe nitüzke.» Subjektuak ez dio entzuleriari beste aukerarik uzten, «harriak ere» bere alde egongo liraketelako. Hil ondorengorako hausnarketa horrek, beraz, ondorengoengan aldeko sentimendua sortu nahi du.

Neska ontziratuaren kasuan, nahiz eta protagonistak etxera, gurasoengana, joateko desioa hamargarren ahapaldian adierazten duen, hausnarketa ez da ageri protagonistaren ahoz, baizik eta laguntzaileen ahoz. Aurreko baladetan emakumezko subjektua izan da enpatia bila ari izan dena; Neska ontziratuan, ordea, laguntzaileen bidez egiten da hil ondorengorako gogoeta , beraiek baitira «aita-amen porturat» neskatila heltzea nahi dutenak.

Atharratze jauregian baladaren aukeratutako ereduan, hasieran agertzen da hausnarketa (guztietan horrela ez den arren). Andre Emilirekin antzekotasun handiak ditu bigarren ahapaldiak. Bertan, zuzen aurpegiratzen dio aitari 
berarekin egindako laidoa. Ez dio, aurreko kasuetan bezala, zalantzari zirrikiturik uzten: subjektuak bere arrazoia aldarrikatzen du, eta beste pertsonaia batengan, bere amarengan hain zuzen, kokatzen du berarekiko enpatia. Maite izan duenarengan itzuli nahi du protagonistak balada honetan, nahiz eta borroka hau galdu duen, ama bizirik balu amaiera bestelakoa izango litzatekelakoan.

Aurkariaren papera betetzen duten gizonen jarrerari ere erreparatu behar zaio, garatuz doa eta. Frantziako anderea deiturikoan, protagonistak lagun izan duen senargaia gero aurkari bihurtzen da; senargaia ez da bere autoritateari eusteko gai, eta, amaren mendeko seme izatera itzultzean berriro, emakumezkoek paira dezaketen arriskua areagotu egiten da. Senarrak amaren mehatxupean emaztea hiltzen duenean, bere burua libratu bezala egiten du, eta hilketaren erantzukizuna errainaren gain, biktimaren gain, jartzen du . Honela, emakumezkoak aurkari gisa agertzen dira lau baladatan: Andre Emilin, Frantziako Anderean, Neska ontziratuan eta Atharratze jauregian (ez Urrututiako anderean, zeinetan agertzen den emakumezko pertsonaia bakarra protagonista den). Neska ontziratuaren kasuan, aurrena lagun gisa agertzen den kapitaina gero aurkari agertzen da, berriro ere arriskuaren ideia indartuz. Hala ere, kasu honetan, neskaren heriotzaren ostean kapitainaren damua agertzen da; protagonistarekin enpatia bilatzen da modu honetan, aipatutako hausnarketaren bidez ondorengoek istorio hau gogoratzea eta emakumezkoaren zuzentasuna bermatzea. Hala ere, beste irakurketa bat ere egin liteke agian, beste behin, gizonezkoaren damuak bere gizatasuna jartzen baitu mahai gainean, azken momentuko damuarekin erantzukizuna gutxituz. Laguntzaileak, berriz, gizonezkoak dira guztietan; Atharratze Jauregia izenekoan ahizpa laguntzaile gisa agertzen den arren, amaieran aurkari bezala azaltzen da, eta ama ere balizko laguntzaile gisa aipatzen duen arren, ez dago bizirik, laguntzaile errealik agertzen ez dela ageri balada honetan. Aztertutako balada guztietan ere, ustez laguntzaileak edo heroiak izan beharko zirenek aurkariaren rola betetzen dute. Gizarte eredu nagusiaren arabera, familiako kideek laguntzaile izan beharko lukete, eta familiaz kanpokoak erasotzaile. Aztertutako bost baladetan, berriz, etxekoek betetzen dute, bai zuzen bai zeharka, erasotzailearen rola: gurasoek emakumeak engainatu, saldu, eta ezkontzera behartzen dituzte; senarrek, jipoitu eta hil egiten dituzte. Bestalde esan behar da, Proppek proposatutako funtzioetan ez bezala, lan honetan aztertzen diren baladetan ezkontza ez dela «sari» edo ipuinaren irtenbide, baizik eta arazoaren jatorri.

Rolak eraldatuta ageri ohi dira, beraz. Amodioa arrisku gisa da ulertua bostetan, emakumearen bizitza baldintzatzen duena; honek babesgabezia egoeran uzten ditu protagonistak.

Aktanteen azterketak azaltzen du, ikusi den bezala, zein den baladen ideologia. Hau kontuan hartuz, ondorengoei igorri nahi zaien mezuari erreparatu behar zaio. Protagonistek, pasabide hauen bidez, bizi duten bortxakeria eta alarma egoeraz lekukotasuna eman nahi dute. Iñarra Garcíaren (1994, 13) hitzetan: 
Zergatik kontatzen ditu kontalariak indarkeriarekin lotuta diren halako ipuinak? Hilketak beste gertakizunen moduan, herrian suertatzen ziren, eta arrazoi honengatik taldearentzako funtzionalak, esanguratsuak ziren narrazioak, hain zuzen, kontatzen ziren. Honelaxe, gertakari hauek kontatzea ez da ustekabeko gauza, zerbaitetarako egiten bada.

Emakume hauek, funtzionaltasuna duen mezua zabaldu nahi dute, bizi duten indarkeria gizartearen aurrean salatzeko eta herriaren memorian itsasteko balio dezakeen mezua ${ }^{6}$. Horretarako, beraien ahotsak ez ezik, gorputzak ere jarri behar dituzte plazan, espazio publikoa okupatuz: «La relación con el gesto es permanentemente estrecha: como la voz misma, aunque de una manera especial y subordinada, proyecta el cuerpo en el espacio de la performance y aspira a conquistarlo, a saturarlo con su movimiento» (Zumthor 2006: 48) . Ahozko adierazpena izateagatik, mezua errazago finkatzen da jasotzaileengan: «El texto con finalidad vocal [...] tiende a imponerse como un bien común del grupo en cuyo seno funciona» (2006: 78).

Esan ote daiteke, baina, baladetan subjektu diren emakumeak errealitatean ere istorio hauen protagonistak izan zirela? Ez dago hau jakiterik. Hala ere, zalantzarik gabe baiezta daiteke gertaerak, funtsean, errealak direla. Iñarra Garcíak honela adierazten du (1994: 16): "Ahozko testuetan kontatzen den bortizkeria, gertutakoa edo irudimenezkoa, betiere nolabait erreala; errealitate fisiko, sinboliko, kultural, eta inkontzienteren islada da.»

Badago, inolaz, errealitate bat emakumezkoek kontatu nahi izan dutena. Baladak kantatzen zituzten emakumezko subjektu haiek hil ondorenerako gogoeta bat egin zuten ondorengoengan eragina izateko asmoarekin. Baladak kantatzen diren aldiro, arestian aipatutako enpatia hori bermatzea dakar: hots, baladen biziraupena. Luzez mantendu den errealitatea da, beraz.

Horrelako egoerak luzez mantendu dira, eta baladetako markoaz gain beste forma batzuetan ere ageri dira (lo-kantak eta Euskal Herrian oso errotuta zeuden eresiak, besteak beste; beste tradizio batzuetan ere ageri dira emakumezko egile eta protagonistak ${ }^{7}$ ). Aztertutako baladekin alderatuz, bai gaian, bai aktanteetan, bai formetan antzekotasun handiak dituzten adibide garbiak ditugu.

Horietariko bat eresiak dira. Garibayk (1854: 176) eresi gutxi batzuk jaso zituen bere idatzietan, Endechas de mugeres que por conservación de esta vejez las he querido referir aquí izendapean, haien artean ezagunena Lasturco Milia delarik. Eresi honetan baladetan aztertutako ezaugarri berdinak ageri dira:

6 Emakumezko eta gizonezko rolen banaketan ezberdintasunak daude. Iñarra Garcíaren hitzetan (1994: 60) «Rolen banaketa oso ageria da: gizonezkoak alor publikokoak betetzen ditu eta emakumeak etxe esparrukoak. Indarkeriak emakumea, sozialki baliogabetuena dena, jotzen du, eta hauxe gertatzen da hain zuzen emakumearen espazio sinbolikoan, gizonezkoen botere soziala indarrez sartzen baita emakumezkoen toki gunean, bai bere burua boterean irauteko edota arlo publikoan ez duen boterea etxean erakusteko.

7 Honen adibidea dira López-Navajasek eta López García-Molinsek (2012: 31) aipatzen dituzten «juglaresas, cantaderas y soldaderas». 
batetik ezkontza exogamikoa medio bortxaz hil den emakume baten istorioa beste emakume batek, bere ahizpak hain zuzen, kantatua; bestetik, hil ondoko gogoeta eta etxekoengana, hots, maite izan dutenengana itzultzeko desioa.

Loa loa txuntxurrun berde, Azkuek 1922an bere kantutegian jasotzen zuena, adibide garbia da ere. Lo kantua izan arren, kontatzen duen istorioa ez da batere inozentea: gizon batek bere emaztea hartu du mandoan, bidean saltzeko edo prostituitzeko intentzioarekin. Abesti honen jatorria ez dago argi, eta herri ondarearen partea da. Mendez mende biziraun badu zentsura guztiak ekidinez, erabiltzen duen hizkeragatik da, ume eta emakumeen munduari dagokiena. Honela adierazten du Paul Zumthorrek (1996, 93):

En los primeros tiempos de la vida y el niño, antes incluso de entablar con él un diálogo hablado, la madre entra en juego readaptando espontáneamente su habla: timbre, tono de voz y ritmo, modulados para canturrear una canción de cuna o enunciar alguna palabra en babytalk... ¿Será esto el fundamento (o el indicio) de una oralidad especificamente femenina [...]?

Oreina bilakatu neska sasi-balada ez da euskal ahozko literaturaren ondarearen parte, frantziar ereduetatik Pierre Lafittek egindako itzulpena baizik (Kaltzakorta 2017: 190). Gure Herria aldizkarian 1965an «Atlanta-Pireneetako sinheste zaharrak» artikuluan izan zen lehenengoz argitaratua (Laffite 1965: 97-121), nahiz eta Europa osoan balada-gai hau oso zabalduta egon. Aztertutako besteetan bezala, indarkeriaz beteriko egoera baten aurrean gaude. Egunez orein bilakatzen neskaren istorioa kontatzen du fabula itxurazko sasibalada honek. Ematen du neskaren aukera izan dela hau, sorginkeriaren bidez lortu baitu dohaina deitzen dion botere hau. Horrela, bigarren ahapaldiaren lehenengo bi bertsotan neskak zera aitortzen du: «Gauez Mayi nauzu, egunaz oreina». Oreina basoarekin erlaziona daiteke; basora joateak, etxetik urruntzeak, arrisku handiak ekar ditzake (Irastortza 2004: 40). Baina ehizarekin ere erlaziona dezakegu orein hitza, honek oreinarentzat arriskua adierazten duelarik. Horrela esaten digu neskak: «etxeko zakurrek / xerkatzen nautena». Badakigu, beraz, basora eskapatzen dela neska, ez dakigu nahita ala behartuta egiten duen, baina badakigu bertan txakurrek jazarri egiten dutela, eta ez edonongo txakurrek: etxeko txakurrak ditu jazarle. Ezin esan dena adierazita geratzen da beraz: anaiek arreba hartzen dute basoan eta bortxatzen dute. Amak, jakin orduko, alabaren bizitzagatik erregutzen du, baina anaiek arreba hil, zatitu, eta mahaira atera dute ordurako sendiak jan dezan. Lehenengo pertsonan ari da hildakoa: «Ni nuk hor lehena / ene haragiaz / beterik dupina». Amak, krimenaz enteratzean, bere buruaz beste egingo du puñala bihotzean sartuta, bere burua zigortuz familia jagon ez izanagatik. Berriro ere bortxaren kontzeptua, familiaren traizioa eta hil osteko gogoeta agertzen dira, eta gure egunetan ere interesa pizten duela froga daiteke, Laffittek jaso ondoren oso kantatua izan baita (Haizea taldea, Amaia Zubiria...)

Bilintxek (Indalecio Bizcarrondo, 1831-1876) Juana Bixenta Olabe abestian jorratzen du ere neskaren erabilera ekonomikoa amaren partez. Itxaro Bordak Argia aldizkarian bertso hauek oso ondo aletzen zituen «Juana Bixenta, ez etsi!» artikuluan (2018). Juana Bixentaren amak Jaun nagusiarengana bidali 
du etxe-saria ordaintzeko epea atzera diezaion, jakinda alabaren edertasun fisikoak nagusia baretuko duela. Honek, hasieratik adierazten du neskarengandik zer lortu nahi duen, neska babesgabezia egoeran dagoelarik ( «Logratutzea, erraz halare, / nahiz hori ta beste zernahi gauza're, / seguru dela esan amari, /zu baldin bazatoz mandatari»). Indarkeriaren ideia argi azaltzen da hurrengo bertsoetan: «Ez zoazela! / Portatu zaite nik nahi bezela, / gaur etxera joan ez zaitezela!». Bordaren hitzetan, «Bortxa edo gorenetik apalenera harilkatu indarkeria susmoa hemen errotzen da. Hain gozoa eta hitzetan zabala zirudien gizona une honetan zakar azaltzen da, bere kutizia neskaren begitartera aurtikitzen duela!». Ohorea aipatu behar du Juana Bixentak bere burua salbatzeko: « Lotsa gogorra! / Sufritzen dago gaur nire honra / penaz malkuak darizkit horra!». Orduko gizarte kristauak eskatzen zuen bezala, amaiera alaia du Juana Bixenta Olabek eta neska eta Jaun Nagusia ezkontzen dira. Hala ere, bortxa ideia eta amaren traizioa argi azaltzen dira; izan ere, «Ama horren itxura arketipikoa dela erran genezake: amak ezkonduak, amak salduak, amak igorriak franko baitira euskal kantetan.» (Borda, 2018).

Ondorioz, azpimarra daiteke badagoela, beraz, errealitate bat baladak kantatzen zituen emakumeek bizi izan zutena eta mendez mende guregana heldu dena. Bigurik aipatzen zuen (Biguri, 1990: 72) XIX. mendean, Erromantizismoaren garaian, eman zela herri-poesia eta, hain zuzen ere, baladen berraurkikuntza, eta hau ez da kasualitatea. Balada hauen egileak edo igorleak ez ziren emakume ahulak, eta inposaturiko ezkontzen aurka mintzatu ziren, nor maitatu aukeratu ahal izateko, beraien bizitzen jabe izateko.

Zoritxarrez, emakumeen kontrako indarkeria mahai gainean dagoelako, baladek ez dute gaurkotasunik galdu: emakumezkoen salerosketa, bortxaketak, indarkeria eta hilketa matxistak, ume desagertuak... horiek guztiak dira gaur egun ulertzen ditugun gaiak, gure beldur barne-barnekoenekin konektatzen dutenak. Hor datza, hain zuzen, gureganaino heldu izanaren gakoetako bat.

Emakume protagonisten gorputza saldua eta erasotua izan zen; gorputza erabili zuten, plazara ateraz, mezua igortzeko, eta hor datza oraindik ulergarria izatearen beste gako bat: ahozko literaturaren baliabide formalen indarrean.

En cada grupo social eso que llamamos sus tradiciones orales constituyen una red de intercambios vocales vinculados con comportamientos más o menos estrictamente cifrados cuya finalidad esencial consiste en mantener la continuidad de una percepción de la vida y de una experiencia colectiva sin las cuales el individuo quedaría abandonado a su soledad, si no a su desesperación (Zumthor 1985: 4).

Egindako azterketatik, beraz, zera da ondoriozta daitekeena: euskal literatura testuinguruan gordean egon den beste tradizioa baten aurrean gaude; forman eta kontzeptuetan oso antzerakoak diren lanak dira; lehenengo pertsonan daude kontatuta, emakumea subjektu protagonikoa da; familiaren rola eraldatuta agertzen da, maitasuna arrisku gisa aurkeztua; hala ere, gogoetarako lekua dago, ondorengoei mezua igortzeko nahi sendo bat. Lekukotasuna emateko, emakume hauek plazak hartu behar izan zituzten, bortxa eremu domestikotik publikora 
eramanez, mezua zabaltzeko helburu irmoarekin. Balada hauek kantatzera ausartu ziren emakumeak emakume kementsuak izan ziren, eta gutxietsi egiten zituen errealitate baten aurka altxatu ziren. Haien izenak galdu egin baditugu ere, igorritako mezua ez da, aldiz, galdu: dagokien lekua ematea merezi dute orain, kantatzen jarraitzea, ulertzea, estimatzea.

\section{BIBLIOGRAFIA}

Azkue, R. M. d. (1922) Loa loa txuntxurrun berde (herri ondarea). [http://www. eusko-ikaskuntza.eus/es/fondo-documental/cancionero-vasco/ab-283/]

Barbier, J. eta Dufau, C. (1921-1926) «Kantatuz», Gure Herrian, Baiona.

Borda, I. (2018) «Juana Bixenta, ez etsi!», Argia, 2068, 41-43. or.

Biguri, K. (1990) «Euskal ahozko literatura tradizionalari buruzko ikerketa XX. mendean». Anuario del Seminario de Filología Vasca Julio de Urquijo, XXIV-1, 1990, 63-92. or. [https://www.ehu.eus/ojs/index.php/ASJU/article/ view/8123/7275]

Ceballos Viro, I. (2010) El romancero tradicional y las relaciones de parentesco: la suegra malvada, Madrid, Universidad Complutense de Madrid. [https://www.europeana.eu/portal/es/record/9200101/BibliographicResource_1000126632044.html]

Cid, J. A. (2010) «Re-deconstruyendo la balada: Atharratze Jauregian», Anuario del Seminario de Filología Vasca Julio de Urquijo, XLIV-2, 2010, 155-220.or. [http://www.ehu.es/ojs/index.php/ASJU/article/download/7311/9151]

Chao, J. A. (1836) Voyage en Navarre pendant l'insurrection des Basques de 1830-1835, avec portraits et costumes, Paris, Artus Bertrand.

Eliade, M. (1955) «Littérature orale», Encyclopédie de la Pléiade: Histoire des Littératures, Collectif. Paris, Gallimard, 3-24.or.

Etxebarria I. + Kaltzakorta J. (2009) Herri literatura, Gasteiz, Eusko Jaurlaritza,[https://www.euskadi.eus/contenidos/informacion/eu_mintzagai_bilduma_aurkezpen/eu_aurkezp/adjuntos/05-Herri_Lit.pdf]

Etxeberria Ayesta J. M. (1999) Zeberioko kantak, Oiartzun, Sendoa.

Eusko Ikaskuntza, Cancionero vasco, <http://www.eusko-ikaskuntza.eus/es/ fondo-documental/cancionero-vasco/ab-283/> tik jasoa. Azken bisita [201911-11].

Douglass, W. (1973) «Familia, casa y grupo doméstico», Muerte en Murélaga: el contexto de la muerte en el Pais Vasco, Barcelona, Barral.

Euskaltzaindia (2008) Literatura terminoen hiztegia. Bilbo, Euskaltzaindia.

Garibay, E. d. (1854) Memorias. Memorial histórico español, VIII Madrid. [https://www.euskalmemoriadigitala.eus/handle/10357/4861] 
Haritschellar, J. (1963) «Baigorriko zenbait kontu». Gure Herria, 243-256.or. .

Humboldt, W. (1817) Beritchtigungen und Zusätze zum ersten Abschnitte des zweytem Bandes des Mithriates über die Cantabrische oder Baskische Sprache. Berlin, In der Vossichen Buchhandlund.

Iñarra García, M. J. (1994) Hilketa Azkue eta Barandiaranen ahozko ipuin eta ele zaharretan, Madrid, UNED.

Irastortza, T. (2004) «Amodioaren geografia». Hegats literatur aldizkaria, 36 [https://www.idazleak.eus/fitxategiak/dokumentuak/aldizkariak/hegats36. pdf]

Irastortza, T. (2020) Euskarazko literatura eta letren sorkuntzako emakumeen eta gizonen egoera, Gasteiz, Eusko Jaurlaritza.

Jaurgain, J. d. (1899). «Quelques légendes poétiques de Pays de Soule», La tradition Au Pays Basque. Paris, Aux Bureaux de la Tradition Nationale, 349-409.or.

Juaristi, J. (1987) «La balada vasca de la muchacha ciervo», Anuario del Seminario de Filología Vasca Julio de Urquijo XXI-3, 917-926.or. [https://www. ehu.eus/ojs/index.php/ASJU/article/view/7941/7099]

Kaltzakorta J. (2017) Euskal baladak. Baladas vascas (antología), Bilbao, Muelle de Uribitarte editores, S.L.

Kaltzakorta, J. (2017) Euskal baladak: azterketa eta edizio kritikoa, Bilbao, Labayru Fundazioa.

Kortazar, J. (1986) «Neska ontziratuaren baladaren inguruan», Eusko Ikaskuntzen nazioarteko aldizkaria, 31-3, 891-904.or.

Laffitte, P. (1965) «Atlantika-Pirine-etako sinheste zaharrak», Gure Herria, 37-2 , 97-121.or.

Lakarra, J.+ Biguri K. + Urgell B. (1983) Euskal baladak antologia eta azterketa, Donostia, Hordago.

Leizaola, J. M. d. (1969) Romances vascos y literatura prehistórica, Buenos Aires, Editorial Vasca Ekin.

López-Navajas, A. + López García-Molins, Á. (2012) «El desconocimiento de la tradición literaria femenina y su repercusión en la falta de autoridad social de las mujeres». Quaderns de Filologia. Estudis literaris, Vol. XVII: Valencia, Universitat de València, 27-40.or.

Oihenart, A. (1967) «L'Art Poetique Basque. [Pierre Laffiteren argitarapen eta oharrak]». Gure Herria, 39-4, 205-229.or.

Onaindia, S. (1954) Milla euskal olerki eder. Amorebieta, Larrea. [https:// www.euskerazaleak.biz/PDF/idazleak/Aita\%20Santi\%200naindia/Liburuak/1954/Mila\%20Euskal\%20Olerki\%20Eder\%20627.pdf] 
Orpustan, J. B. (1989) «Trois poémes basques du XVIII siécle (1766) sur la vallée d'Oses», Hommage au Musée Basque. Baiona, Sociéte des Amis du Musée Basque, 531-573.or.

Paya, X. (2013) Ahozko Euskal Literaturaren Antologia, Donostia, Etxepare Euskal Institutua.

Propp, V. (1977) Morfología del cuento, Madrid, Editorial Fundamentos.

Urquizu P. et al. (2000) Historia de la literatura vasca, Madrid, UNED.

Vansina, J. (1066) La tradición oral, Barcelona, Labor.

Zavala A. (1996) «Kontapoesia zaarrari buruz». Auspoaren auspoa II (Itzaldiak/ Conferencias). Oiartzun, Sendoa, 45-68.or. [https://www.euskaltzaindia.eus/ dok/iker_jagon_tegiak/auspoa/18437.pdf]

Zumthor, P. (1985) «Permanencia en la voz», El correo: una ventana abierta al mundo, XXXVIII-8, 4.

Zumthort, P. (1991) Introducción a la poesía oral, Madrid, Taurus.

Zumthor, P. (2006) La poesía y la voz en la civilización medieval, Madrid, Adaba. 
